\title{
Attendees' motivation and emotional satisfaction of cultural festivals: a case study of Ojude Oba Festival, ljebu-Ode, Nigeria
}

\section{Oladunni Philip Adesiji}

\author{
Department of Art and Industrial Design, \\ Moshood Abiola Polytechnic, \\ Abeokuta, Nigeria \\ Email: philola10@gmail.com \\ *Corresponding author
}

\section{Adeogun Olajumoke}

Department of Hospitality, Leisure and Tourism Management, Moshood Abiola Polytechnic, Abeokuta, Nigeria

Email: olajumokeabimbola@yahoo.com

\begin{abstract}
Cultural festivals and tourism destinations have always attracted interest of different attendees, tourists and adventure makers to satisfy their emotional needs; one of such festivals is Ojude Oba Festival by the Ijebus which provides a medium for educating and re-orienting visitors on their cultural practices in social and economic life, preservation and communicating their cultural heritage to the present and future generations. However, festival attendants air their views on their satisfaction of the festival attended on overall and attribute-limited scales. Quantitative approach was employed in identifying tourists' motivations for attending Ojude Oba Festival, using the questionnaire it can be established through findings of this research that the majority of the attendees are youth whose motivation for attending the festival is majorly cognitive that is, desirous to explore, seeking intellectual development or to acquire information; their emotional feelings show that the majority of the attendees had the feeling of happiness and being joyful mostly with Regberegbe and majority were most surprised with the cultural dancers of various categories.
\end{abstract}

Keywords: Ojude Oba; cultural festival, attendees' motivation; emotional satisfaction; tourism; Ijebu; destination emotion scale; Regberegbe; Nigeria.

Reference to this paper should be made as follows: Adesiji, O.P. and Olajumoke, A. (2022) 'Attendees' motivation and emotional satisfaction of cultural festivals: a case study of Ojude Oba Festival, Ijebu-Ode, Nigeria', Int. J. Cultural Management, Vol. 1, No. 1, pp.92-106.

Biographical notes: Oladunni Philip Adesiji holds a Bachelor of Technology in Industrial Design and Master of Technology in Graphics, both from Federal University of Technology, Akure, Nigeria. He lectures at the Department of Art and Industrial Design, Moshood Abiola Polytechnic, Abeokuta, Nigeria. His teaching and research experience has been majorly in graphic art, printmaking, user experience, aesthetics in human-computer interaction, cognitive and emotional aspects of aesthetics in everyday design experience. 
Adeogun Olajumoke is currently a $\mathrm{PhD}$ candidate at the Department of Wildlife and Ecotourism Management, University of Ibadan, Ibadan, Nigeria. She serves in a lecturer position at the Department of Hospitality, Leisure and Tourism Management, Moshood Abiola Polytechnic, Abeokuta, Nigeria teaching courses in food and beverage service, tourism transportation, accommodation operations, front office operations with research works interest in ecotourism promotion, indigenous food, gastronomy, health support cuisines, ecotourism for environmental and cultural sustainability.

\section{Introduction}

Cultural festivals and tourism destinations have always attracted interest of tourists and adventure makers to satisfy their emotional needs, escape from routine life, boredom, catch fun; learn new things, and advance career interest; experience the pleasure afforded by the activities; enjoy moments with people of common opinions, get means to express themselves; as well as meet old friends and make new ones. Nigeria boasts of diverse ethnic groups with unique cultures, each of these has a particular cultural root celebrated as festival or adhered as religion. The festivals are portrayed to bring one form of blessing or the other to the participants thereby people from across the world attend them; this trend precede the idea of cultural tourism which has expanded the frontiers of major festivals in Nigeria. One of such festivals is Ojude Oba Festival by the Ijebus. As Owusu-Frempong (2005) opines, African festivals are "medium of cultural education and inter-generational communication and play an important role in the preservation of our cultural heritage, transmitting knowledge and our experiences as a people to future generations". However, festival attendants air their views on their satisfaction of the festival attended on overall and attribute-limited scales. Therefore, organisers must measure performance and competitiveness of their festival and destination based on tourists' experience; this will advance fulfilling objective of the festival or the tourism destination as well as increase tourism's potential for economic diversification by attracting more visitors, create cultural image on the global scene and profitability by increasing employment opportunities of the local people, that is the host community. On the part of the visitors, City Tourism and Culture (2005) as cited by Csapo (2012) submits that "cultural events offer the tourist additional reasons to visit a place over and above the regular cultural product offered. Often because events are one-off and take place in a limited timeframe and because festivals offer a concentrated and often unique offering in a limited time period, they form an additional reason for cultural tourists to visit a place. They can cause a place to rise on the shortlist of places the tourist has in his or her mindset of attractive destinations. Festivals and events are both effective instruments in attracting first time visitors as well as repeat visitors due to the differential advantage they can offer".

According to Wang (2016), understanding satisfaction is important as satisfaction contributes to business opportunities, better financial performance, and greater competitiveness; Abubakar and Mavondo (2014) opines that emotional reactions to the tourism experience are fundamental determinants of post-consumption behaviours such as satisfaction, intention to recommend, attitude judgements and choice. This study aims to identify tourists' motivations for attending Ojude Oba Festival; determine attributes 
affecting the tourist's overall satisfaction of the festival; and which motivation has the most significant influence on tourists' attribute and overall satisfaction of the festival.

\subsection{Statement of problem}

Ramukumba (2017) points out that effective marketing is impossible without identifying, understanding, and prioritising consumers' motivation. Since competition among festivals and destinations is increasing, the need for information on festivals, specifically analysis of motivations for attending festivals and events has become important. Kocabulut and Kilcarsalan (2017) citing previous studies, reports that event managers should make every effort possible to fully understand the motives of festival attendance in order to provide better services for them; since motives are a powerful predictor of satisfaction and a significant aspect in the decision making process, the exploration of the visitors' motives can lead to advanced levels of attendance. In other words, motivations represent the major driving power in explaining human behaviour and represent the personal psychological components that are likely to be satisfied through tourism activities (Chang and Yuan, 2016). Furthermore, it augments the visitors' satisfaction levels since their needs are met; and lastly it increases the chances for the visitors to revisit the festival, a fact that plays a key role for the economic viability of the festival.

The aim of this study is to assess tourists' motivation for attending cultural festivals; in the light on this, the following were the set objectives of the study:

1 examine tourists' motivation for attending Ojude Oba Festival

2 investigate tourists' satisfaction with the festival attributes as well as overall satisfaction with the festival

3 assess tourists' emotional state with the festival events.

\section{Literature review and conceptual model}

\subsection{History and attributes of Ojude Oba}

Osinusi (2017) in the speech delivered at the World Press Conference for Ojude Oba Festival 2017 submits that the festival has been celebrated for about two centuries, it is a classic example and manifestation of religious tolerance as it has its origin in Islam, having lost its religious toga, it has become natural event of social cultural displays of great magnitude as it is graced by sons and daughters of the land and tourists across the globe (Tiamiyu et al., 2017) as it displays culture, cohesion, healthy rivalry, wealth, opulence and development with a dynamic touch of modernity for Ijebus at home, and in diaspora (Areo, 2016). The festival was usually held at the forecourt and the lawns of the main palace, and sometimes when the space was getting inadequate for the hosting of the tumultuous annual guest, the Oba Sikiru Kayode Adetona Golden Jubillee Centre, a monumental edifice was constructed in a record time. 
Attributes of a festival is the instrument that filters the people attracted by the festival, it an important factor for evaluating tourists' satisfaction of a destination, the case of Ojude Oba is not different as it has some unique attributes, prominent among which is Regberegbe, age grade societies which were established in the 18th century. Wompari is the general name given to all the age grade societies; an example, Egbe Gbobaniyi male and female, those born between 1962 and 1964. They dance before the king one after the other. Each group is expected to clad in the latest fashion. They file past in turn with their drummers to pay homage to the king (Fahm, 2015), identified with colourful, contemporary textile materials testifying to their opulence and economic well-being. Other interesting attributes of Ojude Oba Festival are Equestrian Parade, an horse-riding adventure by families of Ijebu warlords, the horses are extravagantly decorated to showcase ceremonial regalia of default Ijebu warrior; Mock War, this features sound of Dane guns during family processions to and from the festival arena with increased frequency at the equestrian parade before the Awujale of Ijebu, it adds glamour and entertaining humour to the horse riding/dancing event; others are live musical performance of indigenous artiste(s), family logos and emblems, etc.

The use of diverse traditional, modern and hybrid attires in identifying the different age-groups plays roles ranging from promoting culture, fashion in vogue, cohesion, communicate socio-economic status and healthy competition, etc. (Diyaolu, 2010; Areo, 2016).

\subsection{Motivation and satisfaction}

Customer satisfaction is mostly defined by means of comparing a product's perceived performance in relation to pre-consumption expectations (Cuadrado-García et al., 2017), and consumers' judgement of whether a product/service provides a pleasurable level of consumption-related fulfilment (Chen et al., 2016). Various studies have established that emotional responses and consumption experience are fundamental determinants of satisfaction and other post-consumption behaviours, e.g., Lee et al. (2003) assert that visitor satisfaction was influenced by motivation, others notes direct relationship between positive emotion and satisfaction such as Dube and Meon (2000), this is important for festival planners because Kozak and Rimmington (2000) notes that satisfaction is important to successful destination marketing; Dunn-Ross and Iso-Ahola corroborated by Ramukumba (2017) further state that knowledge seeking, social interaction and escape motivations have significant relationship with tourists' satisfaction. Therefore, to be successful, festivals have to offer satisfactory experiences to their attendees and meet their needs and wants because satisfaction is a major element affecting attendees' experiences (Akhoondnejad, 2016).

\subsection{Destination emotion scale}

Destination emotion scale (DES) developed by Hosany and Gilbert (2010) is a 3-subscale, 15-item instrument which displays solid psychometric properties in terms of unidimensionality, reliability and validity of its underlying dimensions. The tree dimensions, that is, sub-scales are theoretically consistent with past and other recent 
conceptualisations of emotion in consumer research. It utilises the three dimensions of love, joy and positive surprise to measure tourists' emotional experience of the festival of discourse. Each domains has five items which are love - tenderness, love, caring, affection, and warm-hearted; joy - cheerful, pleasure, joy, enthusiasm and delight; finally, positive surprise - amazement, astonishment, fascinated, inspired and surprised.

Results provide an overwhelming support for the validity of the destination emotion scale in other contexts by establishing unidimensionality, reliability, convergent, discriminant and nomological validity. The items in the emotional experience were adapted from Hosany and Gilbert's (2010) destination emotion scale (DES).

\section{Methodology}

This study adopts the quantitative approach using the questionnaire as research instrument for eliciting responses from tourists at the 2018 edition of Ojude Oba Festival, the respondents were selected on cross-sectional basis since the survey research is targeted at capturing the tourists' emotional experience, festival attributes and overall satisfaction of the event. The entire demographic category of the spectators were those old enough to decide to voluntarily fill-out the questionnaire found at the festival venue and its surrounding. The tourists move from one place to another even within the event venue to capture the festival essence, meet friends and family as well as take photographic shots of interesting moments from time-to-time.

\subsection{Questionnaire design}

The questionnaire consists of five (5) parts. The first part is the socio-demographic information of the respondents, this section adds the festival related demographics of the respondents such as source of information about the festival, number of previous visits, visits to other festivals in time past. The second part measures the tourists' motivation based on 5-point Likert scale ranging from strongly disagree (1) through strongly agree (5). This is followed by the 15 items categorised under 3 dimensions which were adapted (from Hosany and Gilbert, 2010) to measure festival emotional experience of tourists. The preliminary part of the tourists' satisfaction is built on the three sub-scales.

\subsection{Results of the investigation and discussion}

In order to execute the aim of this study which is to assess tourists' motivation for attending cultural festivals, one hundred questionnaires (100) were administered out of which 94 were returned appropriately filled by the respondents, this signifies $94 \%$ return rate.

Table 1 presents the demography of the respondents to the survey. 
Table 1 Demography of the respondents

\begin{tabular}{|c|c|}
\hline & Frequency (\%) \\
\hline Age & $\begin{array}{c}<20 \text { years }-19(20.2 \%) ; 21-30 \text { years }-39(41.5 \%) \\
31-49 \text { years }-23(24.5 \%) ; 50-64 \text { years }-11(11.7 \%) \\
65 \text { years and above }-2(2.1 \%) ; \text { Total }-94(100 \%)\end{array}$ \\
\hline Gender & $\begin{array}{c}\text { Male }-50(53.2 \%) ; \text { Female }-44(46.8 \%) \\
\text { Total }-94(100 \%)\end{array}$ \\
\hline Marital status & $\begin{array}{l}\text { Single }-55(58.5 \%) ; \text { Married }-35(37.2 \%) \\
\text { Separated - } 1(1.1 \%) ; \text { Divorced - } 0(0 \%) \\
\text { Widowed - } 3(3.2 \%) ; \text { Total - } 94(100 \%)\end{array}$ \\
\hline Academic certificate & $\begin{array}{c}\text { SSCE - } 26 \text { (27.7 \%); OND/NCE - } 24(25.5 \%) ; \\
\text { HND/B.SC - 31 (33\%); Master degree - 8 (8.5\%); } \\
\text { PhD - 5 (5.3\%); Total - } 94(100 \%)\end{array}$ \\
\hline Average monthly income (naira) & $\begin{array}{c}<10,000-22(23.4 \%) ; 11,000-20,000-15(16 \%) ; \\
21,000-30,000-15(16 \%) ; 31,000-49,000-11(11.7 \%) ; \\
50,000-75,000-8(8.5 \%) ; 76,000-100,000-13(13.8 \%) ; \\
101,000-200,000-6(6.38 \%) ; \text { Above } 200,000-4(4.25 \%) ; \\
\text { Total - } 94(100.0 \%)\end{array}$ \\
\hline Number of previous visits & $\begin{array}{c}\text { Never before }-4(4.3 \%) ; \text { Once }-48(51.1 \%) \\
\text { Twice }-13(13.8 \%) ; \text { Thrice }-6(6.4 \%) ; \\
4-10 \text { times }-5(5.3 \%) ; \text { More than } 10 \text { times }-18(19.1 \%) \\
\text { Total } 94(100 \%)\end{array}$ \\
\hline Travel companion & $\begin{array}{c}\text { Alone }-16(17 \%) ; \text { Spouse }-12(12.8 \%) ; \\
\text { Family }-45(47.9 \%) ; \text { Friends }-15(16 \%) ; \\
\text { School/organisation }-4(4.3 \%) ; \text { Others }-2(2.1 \%) ; \\
\text { Total } 94(100 \%)\end{array}$ \\
\hline Mode of travel & $\begin{array}{c}\text { Private car }-42(44.7 \%) ; \text { Public transport }-42(44.7 \%) \\
\text { Airplane }-6(6.4 \%) ; \text { Trekking }-2(2.1 \%) \\
\text { Waterway }-2(2.1 \%) ; \text { Total }-94(100 \%)\end{array}$ \\
\hline Information source & $\begin{array}{c}\text { Word of mouth }-36(38.3 \%) ; \\
\text { Newspaper/magazine }-10(10.6 \%) ; \\
\text { Television }-10(10.6 \%) ; \text { Radio jingles }-(9.6 \%) ; \\
\text { Internet }-3(3.2 \%) ; \text { Others }-8(8.5 \%) ; \\
\text { Total }-94(100 \%)\end{array}$ \\
\hline
\end{tabular}

The demographics show majority of attendees fall in the age range, 30-39years (41.5\%), which is an indication of the high level of interest among the youth; implying that Ojude Oba festival has content and relevance for the youth, despite being a cultural/traditional event; the educational level of the respondents is another pointer to the intellectual development embedded in the festival as more than $71 \%$ of the respondents are having minimum of OND/NCE.

\subsubsection{Tourists' motivation}

Table 2 shows attendees motive for attending the festival; as indicated, the topmost motivation is cognitive [that is intellectual development - the drive to acquire information, knowledge, understanding social environment, curiosity, exploration; it covers learning, self-education (Femi and Adesiji, 2019)], slightly followed by enjoyment (the drive to experience pleasure afforded by the activities). This is followed by the attendees' desire to meet old and new friends in a bid to socialise and it is closely ranked 
after the need to be with people who enjoy same things, share common opinions and self-expression. The least ranked motivation is the escapism, which is the desire to escape routine life, boredom, catch fun, etc.

Table 2 Attendees' motivation factors

\begin{tabular}{lcc}
\hline & Mean & $S D$ \\
\hline Escapism & 3.69 & 1.39 \\
Cognitive & 4.11 & 1.07 \\
Enjoyment & 4.07 & 1.03 \\
Same view & 3.90 & 1.08 \\
Old and new friends & 3.95 & 1.07 \\
\hline
\end{tabular}

The results in Table 2 informs us that the primary driver of tourists' attendance at Ojude Oba festival is novelty, education and intellectual development, while secondarily, tourists seek enjoyment, therefore, concrete attention must be directed towards enhancing the intellectual content/relevance of the festival as far as the visitors are concerned across the demographics. This result agrees with Crompton and McKay (1997) and Iolanda et al. (2014).

Table 3 Attendees satisfaction with festival attributes

\begin{tabular}{lccccccc}
\hline & $\begin{array}{c}\text { Extremely } \\
\text { dissatisfied }\end{array}$ & Dissatisfied & Indifferent & Satisfied & $\begin{array}{c}\text { Extremely } \\
\text { satisfied }\end{array}$ & Mean & SD \\
\hline Hotel & 19 & 15 & 15 & 28 & 17 & 3.10 & 1.42 \\
P.A. sound & $(20.2 \%)$ & $(16 \%)$ & $(16 \%)$ & $(29.8 \%)$ & $(18.1 \%)$ & & \\
Time & 6 & 15 & 10 & 47 & 16 & 3.55 & 1.14 \\
& $(6.4 \%)$ & $(16 \%)$ & $(10.6 \%)$ & $(50 \%)$ & $(17 \%)$ & & \\
General organisation & 9 & 11 & 10 & 37 & 27 & 3.66 & 1.28 \\
& $(9.6 \%)$ & $(11.7 \%)$ & $(10.6 \%)$ & $(39.4 \%)$ & $(28.7 \%)$ & & \\
Local dishes & 5 & 14 & 12 & 44 & 19 & 3.62 & 1.13 \\
Regberegbe & $(5.3 \%)$ & $(14.9 \%)$ & $(12.8 \%)$ & $(46.8 \%)$ & $(20.2 \%)$ & & \\
& 16 & 6 & 19 & 29 & 24 & 3.36 & 1.38 \\
Horse riding & $(17 \%)$ & $(6.4 \%)$ & $(20.2 \%)$ & $(30.9 \%)$ & $(25.5 \%)$ & & \\
Mock war & 8 & 1 & 11 & 36 & 38 & 4.01 & 1.16 \\
& $(8.5 \%)$ & $(1.1 \%)$ & $(11.7 \%)$ & $(38.3 \%)$ & $(40.4 \%)$ & & \\
Security & 5 & 1 & 5 & 32 & 51 & 4.31 & 1.02 \\
& $(5.3 \%)$ & $(1.1 \%)$ & $(5.3 \%)$ & $(34 \%)$ & $(54.3 \%)$ & & \\
Music & 6 & 1 & 11 & 46 & 30 & 3.99 & 1.03 \\
& $(6.4 \%)$ & $(1.1 \%)$ & $(11.7 \%)$ & $(48.9 \%)$ & $(31.9 \%)$ & & \\
Souvenir & 8 & 3 & 10 & 40 & 33 & 3.93 & 1.7 \\
& $(8.5 \%)$ & $(3.2 \%)$ & $(10.6 \%)$ & $(42.6 \%)$ & $(35.1 \%)$ & & \\
& 5 & 5 & 11 & 28 & 45 & 4.10 & 1.14 \\
& $(5.3 \%)$ & $(53 \%)$ & $(11.7 \%)$ & $(29.8 \%)$ & $(47.9 \%)$ & & \\
& 7 & 5 & 13 & 35 & 34 & 3.89 & 1.18 \\
& $(7.4 \%)$ & $(5.3 \%)$ & $(13.8 \%)$ & $(36.2 \%)$ & $(36.2 \%)$ & & \\
\hline
\end{tabular}




\subsubsection{Tourists' satisfaction with the festival attributes}

The mean perception of each of the eleven (11) festival attributes are above average, Horse riding has the highest means rating, $4.31(S D=1.02)$, followed by music, 4.10 $(S D=1.14)$ and Regberegbe, $4.01(S D=1.16)$, while hotel and accommodation-related matters has the least mean rating, $3.10(S D=1.42)$. This is a pointer to areas that require germane attention in order to maximise tourists' experience in the festival.

\subsubsection{Tourists' overall satisfaction with the festival}

Figure 1 shows overall satisfaction rating of the respondents with $36 \%$ respondents satisfied and 50\% very satisfied accounting for $86 \%$ satisfaction rating; this is an offshoot of good performance rating of each festival attribute by the respondents.

Figure 1 Attendees' overall satisfaction with Ojude Oba Festival (see online version for colours)

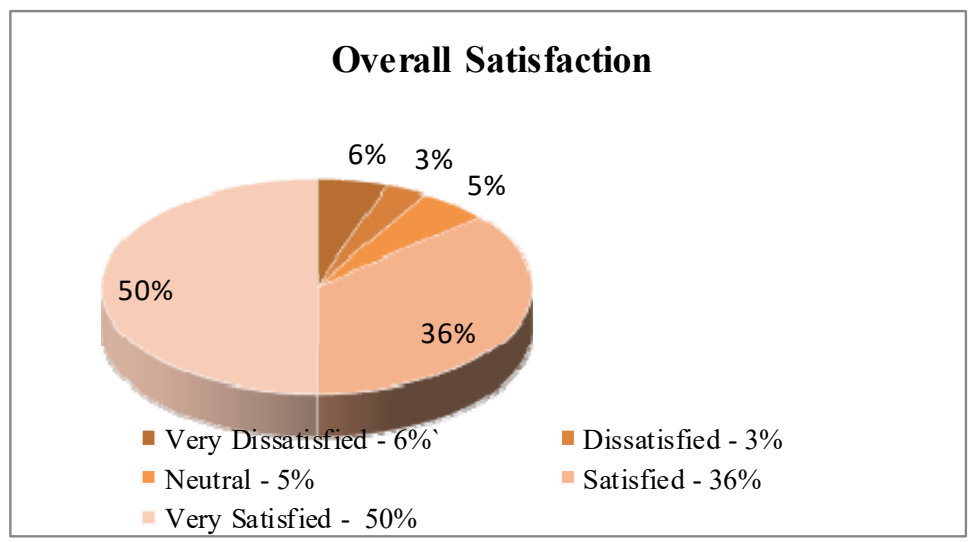

Table 4 Frequency table: intention to revisit and recommend

\begin{tabular}{lcc}
\hline & Revisit & Recommend \\
\hline Yes & $88(93.6 \%)$ & $87(92.5 \%)$ \\
No & $5(5.3 \%)$ & $7(7.45 \%)$ \\
\hline
\end{tabular}

Table 4 indicates that $93.6 \%$ of the respondents have the intention to revisit the festival while $87 \%$ will recommend the festival to other people. This will increase tourists' loyalty base for the Ojude Oba festival as well as increase the leading effect of word-of-mouth; Barnes et al. (2014) opines that there is a strong body of literature linking visitor satisfaction, typically seen as a post-purchase assessment and destination loyalty in the tourism context. Building on research in marketing, evidence has shown that more satisfied customers tend to purchase more products or services and to spread positive word-of-mouth that is likely to influence others to become customers and this has been shown to hold in many different contexts, including retail banking, mobile commerce, hotels and. In the tourism context, the same relationships have been empirically supported in numerous studies (Báez-Montenegro and Devesa-Fernández, 2014). 


\subsubsection{Relationship between overall satisfaction and intention to recommend}

The relationship between overall satisfaction and intention to revisit and recommend was investigated using Pearson product moment correlation coefficient. Preliminary analysis were performed to assure no violation of the assumptions of normality, linearity and homoscedasticity; there was significant positive correlation between the variables, Overall satisfaction and intention to revisit, $\mathrm{r}=0.414, \mathrm{n}=94, \mathrm{p}<0.001$, and $\mathrm{r}=0.355$, $\mathrm{n}=94, \mathrm{p}<0.001$ for the relationship between Overall satisfaction and intention to recommend. In the same vein, overall satisfaction significantly predicts revisit intention, $\beta=0.414, \mathrm{t}(94)=4.36, \mathrm{p}<0.01$; overall satisfaction significantly predicts intention to recommend, $\beta=0.355, \mathrm{t}(94)=3.602, \mathrm{p}<0.01$.

Wang (2016) submits that from previous studies, a high level of satisfaction encourages tourists to re-visit the destination; satisfied tourists also tell their relatives and friends, providing free advertisement and helping promote increased travel to the destination (Kau and Lim, 2005; Kozak and Rimmington, 2000; Yu and Goulden, 2006). Satisfaction also offers financial competitiveness through a number of ways while repeat purchase and positive word-of-mouth reduces business costs (Sheth, 2001) while Schuckert et al. (2015) adds that people tend to trust peer recommendation more than advertising.

\subsubsection{Influence of motivation on festival attributes satisfaction}

Table 5 explains the contribution of each motivational factor to the festival attribute satisfaction on a regression scale. Same view motivation contributes to most festival attributes, while attendees' satisfaction was not significantly influenced by the motive to meet old and new friends. Against this background, festival attendees' motive of enjoyment, that is the drive to experience pleasure afforded by the activities and the drive to meet old and new friends in a bid to socialise have significant influence on overall festival satisfaction.

Table 5 Effects of motivational factors on festival attributes

\begin{tabular}{lcccc}
\hline Motive & Festival attribute & $B$ & $t$ & $p$-value \\
\hline Escapism & Regberegbe & 0.24 & 2.07 & 0.00 \\
Cognitive & Dishes & -0.34 & -2.37 & 0.01 \\
Enjoyment & General organisation & -0.19 & -1.43 & 0.03 \\
& Horse riding & 0.29 & 2.43 & 0.01 \\
& Mock war & 0.26 & 2.20 & 0.00 \\
& Souvenir & 0.39 & 3.23 & 0.00 \\
Same view & Public address system & 0.39 & 1.93 & 0.00 \\
& General organisation & 0.34 & 1.93 & 0.00 \\
& Dishes & 0.33 & 2.45 & 0.02 \\
& Regberegbe & 0.293 & 2.295 & 0.02 \\
& Security & 0.34 & 2.57 & 0.01 \\
\hline
\end{tabular}


Table 6 Influence of motivation on overall satisfaction

\begin{tabular}{|c|c|c|c|c|c|c|c|}
\hline & & \multicolumn{2}{|l|}{$\beta$} & \multicolumn{2}{|l|}{$t$} & \multicolumn{2}{|l|}{$p$-value } \\
\hline \multicolumn{2}{|l|}{ Escapism } & \multicolumn{2}{|l|}{0.1} & \multicolumn{2}{|l|}{-0.83} & \multicolumn{2}{|l|}{0.41} \\
\hline \multicolumn{2}{|l|}{ Cognitive } & \multicolumn{2}{|l|}{-0.2} & \multicolumn{2}{|l|}{-1.45} & \multicolumn{2}{|l|}{0.15} \\
\hline \multicolumn{2}{|l|}{ Enjoyment } & \multicolumn{2}{|l|}{0.39} & \multicolumn{2}{|l|}{3.33} & \multicolumn{2}{|l|}{0.00} \\
\hline \multicolumn{2}{|l|}{ Same view } & \multicolumn{2}{|l|}{0.04} & \multicolumn{2}{|l|}{0.32} & \multicolumn{2}{|l|}{0.75} \\
\hline \multicolumn{2}{|l|}{ Old and new friends } & \multicolumn{2}{|l|}{0.42} & \multicolumn{2}{|l|}{3.82} & \multicolumn{2}{|l|}{0.00} \\
\hline \multicolumn{2}{|c|}{$F$ test statistic significance } & \multicolumn{6}{|c|}{$F(5,88)=5.08, p=0.00$} \\
\hline \multirow[t]{2}{*}{ Table 7} & n emotiona & scale of atte & adees of $\mathrm{C}$ & de $\mathrm{Oba} \mathrm{Fe}$ & ival & & \\
\hline & $\begin{array}{l}\text { Strongly } \\
\text { disagree }\end{array}$ & Disagree & Neutral & Agree & $\begin{array}{c}\text { Strongly } \\
\text { agree }\end{array}$ & Mean & $S D$ \\
\hline CHEERFUL & $\begin{array}{c}8 \\
(8.5 \%)\end{array}$ & $\begin{array}{c}1 \\
(1.1 \%)\end{array}$ & $\begin{array}{c}9 \\
(9.6 \%)\end{array}$ & $\begin{array}{c}41 \\
(43.6 \%)\end{array}$ & $\begin{array}{c}35 \\
(37.2 \%)\end{array}$ & 4.00 & 1.14 \\
\hline PLEASURE & $\begin{array}{c}3 \\
(3.2 \%)\end{array}$ & $\begin{array}{c}10 \\
(10.6 \%)\end{array}$ & $\begin{array}{c}14 \\
(14.9 \%)\end{array}$ & $\begin{array}{c}36 \\
(38.3 \%)\end{array}$ & $\begin{array}{c}31 \\
(33 \%)\end{array}$ & 3.87 & 1.09 \\
\hline JOY & $\begin{array}{c}2 \\
(2.1 \%)\end{array}$ & $\begin{array}{c}6 \\
(6.4 \%)\end{array}$ & $\begin{array}{c}10 \\
(10.6 \%)\end{array}$ & $\begin{array}{c}28 \\
(29.8 \%)\end{array}$ & $\begin{array}{c}48 \\
(51.1 \%)\end{array}$ & 4.21 & 1.02 \\
\hline ENTHUSIASM & $\begin{array}{c}3 \\
(3.2 \%)\end{array}$ & $\begin{array}{c}6 \\
(6.4 \%)\end{array}$ & $\begin{array}{c}14 \\
(14.9 \%)\end{array}$ & $\begin{array}{c}27 \\
(28.7 \%)\end{array}$ & $\begin{array}{c}44 \\
(46.8 \%)\end{array}$ & 4.10 & 1.08 \\
\hline DELIGHT & $\begin{array}{c}8 \\
(8.5 \%)\end{array}$ & $\begin{array}{c}7 \\
(7.4 \%)\end{array}$ & $\begin{array}{c}12 \\
(12.8 \%)\end{array}$ & $\begin{array}{c}34 \\
(36.2 \%)\end{array}$ & $\begin{array}{c}33 \\
(35.1 \%)\end{array}$ & 3.82 & 1.24 \\
\hline TENDERNESS & $\begin{array}{c}3 \\
(3.2 \%)\end{array}$ & $\begin{array}{c}8 \\
(8.5 \%)\end{array}$ & $\begin{array}{c}16 \\
(17 \%)\end{array}$ & $\begin{array}{c}30 \\
(31.9 \%)\end{array}$ & $\begin{array}{c}37 \\
(39.4 \%)\end{array}$ & 3.96 & 1.10 \\
\hline LOVE & $\begin{array}{c}4 \\
(4.3 \%)\end{array}$ & $\begin{array}{c}4 \\
(4.3 \%)\end{array}$ & $\begin{array}{c}17 \\
(18.1 \%)\end{array}$ & $\begin{array}{c}36 \\
(38.3 \%)\end{array}$ & $\begin{array}{c}33 \\
(35.1 \%)\end{array}$ & 3.96 & 1.05 \\
\hline CARING & 0 & $\begin{array}{c}9 \\
(9.6 \%)\end{array}$ & $\begin{array}{c}20 \\
(21.3 \%)\end{array}$ & $\begin{array}{c}36 \\
(38.3 \%)\end{array}$ & $\begin{array}{c}30 \\
(31.9 \%)\end{array}$ & 3.93 & 0.95 \\
\hline AFFECTION & $\begin{array}{c}4 \\
(4.3 \%)\end{array}$ & $\begin{array}{c}6 \\
(6.4 \%)\end{array}$ & $\begin{array}{c}20 \\
(21.3 \%)\end{array}$ & $\begin{array}{c}29 \\
(30.9 \%)\end{array}$ & $\begin{array}{c}35 \\
(37.2 \%)\end{array}$ & 3.90 & 1.11 \\
\hline WARM-HEARTED & $\begin{array}{c}7 \\
(7.4 \%)\end{array}$ & $\begin{array}{c}7 \\
(7.4 \%)\end{array}$ & $\begin{array}{c}20 \\
(21.3 \%)\end{array}$ & $\begin{array}{c}38 \\
(40.4 \%)\end{array}$ & $\begin{array}{c}22 \\
(23.4 \%)\end{array}$ & 3.65 & 1.14 \\
\hline AMAZEMENT & $\begin{array}{c}8 \\
(8.5 \%)\end{array}$ & $\begin{array}{c}8 \\
(8.5 \%)\end{array}$ & $\begin{array}{c}11 \\
(11.7 \%)\end{array}$ & $\begin{array}{c}27 \\
(28.7 \%)\end{array}$ & $\begin{array}{c}40 \\
(42.6 \%)\end{array}$ & 3.88 & 1.29 \\
\hline ASTONISHMENT & $\begin{array}{c}3 \\
(3.2 \%)\end{array}$ & $\begin{array}{c}9 \\
(9.6 \%)\end{array}$ & $\begin{array}{c}16 \\
(17 \%)\end{array}$ & $\begin{array}{c}33 \\
(35.1 \%)\end{array}$ & $\begin{array}{c}33 \\
(35.1 \%)\end{array}$ & 3.89 & 1.09 \\
\hline FASCINATED & $\begin{array}{c}2 \\
(2.1 \%)\end{array}$ & $\begin{array}{c}4 \\
(4.3 \%)\end{array}$ & $\begin{array}{c}19 \\
(20.2 \%)\end{array}$ & $\begin{array}{c}41 \\
(43.6 \%)\end{array}$ & $\begin{array}{c}28 \\
(29.8 \%)\end{array}$ & 3.95 & 0.93 \\
\hline INSPIRED & $\begin{array}{c}4 \\
(4.3 \%)\end{array}$ & $\begin{array}{c}7 \\
(7.4 \%)\end{array}$ & $\begin{array}{c}22 \\
(23.4 \%)\end{array}$ & $\begin{array}{c}36 \\
(38.3 \%)\end{array}$ & $\begin{array}{c}25 \\
(26.6 \%)\end{array}$ & 3.74 & 1.06 \\
\hline SURPRISED & $\begin{array}{c}1 \\
(1.1 \%)\end{array}$ & $\begin{array}{c}6 \\
(6.4 \%)\end{array}$ & $\begin{array}{c}20 \\
(21.3 \%)\end{array}$ & $\begin{array}{c}24 \\
(25.5 \%)\end{array}$ & $\begin{array}{c}43 \\
(45.7 \%)\end{array}$ & 4.09 & 1.01 \\
\hline
\end{tabular}




\subsubsection{Attendees emotional state with the festival events}

Joy (mean $=4.21, S D=1.02$ ), enthusiasm (mean $=4.10, S D=1.08)$ and surprise (mean $=4.09, S D=1.01)$ are the topmost emotional state of attendees of Ojude Oba Festival, the resultant effect of this in the three domains of the destination emotion scale is that joy domain (which has the emotions, cheerful, pleasure, joy, enthusiasm and delight), mean $=4.00$, is the most dominant emotional state impacted the attributes of Ojude Oba Festival, this is closely followed by the other two domains, positive surprise (amazement, astonishment, fascinated, inspired and surprised) and love (tenderness, love, caring, affection, and warm-hearted) which has aggregate mean $=3.91$ and 3.88 respectively.

Relating to the findings of Lalith and Fredy-Roberto (2013), that certain emotions such as happiness and excitement were found to be other determinants of memorable tourism experiences; it implies that greater percentage of the attendees of the Ojude Oba Festival will have lasting memory of the emotional experience at the festival since the cumulative mean from the emotional experience table is 3.93.

Table 8 Emotional state of the attendees based on festival attributes

\begin{tabular}{lccc}
\hline Attribute & Most happy & Most loved & Most surprised \\
\hline Regberegbe & $32(34 \%)$ & $24(25.5 \%)$ & $20(21.3 \%)$ \\
Horse riding & $30(31.9 \%)$ & $27(28.7 \%)$ & $21(22.3 \%)$ \\
Mock war & $6(6.4 \%)$ & $1(1.1 \%)$ & $13(13.8 \%)$ \\
Music & $6(6.4 \%)$ & $6(6.4 \%)$ & 0 \\
All & $18(19.1 \%)$ & $6(6.4 \%)$ & $1(1.1 \%)$ \\
Cultural dance & $1(1.1 \%)$ & 0 & $35(37.2 \%)$ \\
Attires & $1(1.1 \%)$ & $8(8.5 \%)$ & $4(4.3 \%)$ \\
Crowd & 0 & $21(22.3 \%)$ & 0 \\
Organisation & 0 & $1(1.1 \%)$ & 0 \\
Total & $94(100 \%)$ & $94(100 \%)$ & $94(100 \%)$ \\
\hline
\end{tabular}

Table 8 indicates strongly individual attendees emotional state based on the festival attributes, Regberegbe, Horse riding and the cultural dance were most mentioned by the respondents because this is an open-ended question where the respondents were asked to write festival attribute that invoke the listed emotions on them. Regebregbe gives the attendees happiness the most, horse riding is the attribute the attendees love the most while the attendees are most surprised by the cultural dance of various forms.

\subsubsection{Relationship between overall satisfaction and emotional experience}

Only items with significant values are recorded and hereby reported.

According to Table 9, Overall satisfaction is significantly correlated with pleasure (joy domain), tenderness (love domain), love (love domain) and astonishment (positive surprise domain); $\mathrm{r}=0.42, \mathrm{p}<0.01, \mathrm{r}=0.45, \mathrm{p}<0.01, \mathrm{r}=0.49, \mathrm{p}<0.01$ and $\mathrm{r}=0.55$, $\mathrm{p}<0.01$ respectively. 
Table 9 Correlation between overall satisfaction and emotional experience

\begin{tabular}{lcc}
\hline & Correlation coefficient $(r)$ & $p$-value \\
\hline Pleasure & 0.42 & 0.002 \\
Tenderness & 0.45 & 0.001 \\
Love & 0.49 & 0.001 \\
Astonish & 0.55 & 0.003 \\
\hline
\end{tabular}

\subsubsection{Test for independence}

The demographic variable, previous visits were tested against the three emotional domains of the DES; the sample includes four attendees $(4.3 \%)$ who have never before visited Ojude Oba Festival, once - 48 (51.1\%); twice - 13 (13.8\%), thrice - 6 (6.4\%), 4-10 times - 5 (5.3\%); more than 10 times - $18(19.1 \%)$ - total $94(100 \%)$. These frequencies are significantly different:

- $\quad \mathrm{x}^{2}(1, \mathrm{n}=94)=150.89, \mathrm{p}=0.000$, Cramer's $\mathrm{V}=0.517-$ joy domain

- $\mathrm{x}^{2}(1, \mathrm{n}=94)=167.10, \mathrm{p}=0.03$, Cramer's $\mathrm{V}=0.544$ - positive surprise domain

- $\mathrm{x}^{2}(1, \mathrm{n}=94)=115.16, \mathrm{p}=0.00$, Cramer's $\mathrm{V}=0.517-$ love domain.

\subsubsection{Influence of emotional experience on overall satisfaction}

Table 10 Regression table of emotional domains and overall satisfaction

\begin{tabular}{lccc}
\hline & $B$ & $t$ & $p$-value \\
\hline Joy domain & -0.2 & -1.93 & 0.04 \\
Love domain & -0.25 & -2.48 & 0.02 \\
Positive surprise & -1.8 & 0.08 & 0.03 \\
\hline
\end{tabular}

\subsubsection{Theoretical implications}

It is hoped that empirical results from this study will guide future researchers in wider applications of destination emotion scale (DES) to successfully measure attendees and tourists' satisfaction. Attendees of cultural festivals are primarily driven by cognitive motivation, that is, seeking novelty, education and intellectual development - they usually want to learn more about the culture, the people, meaning of totems of the festival and this should alongside other paramount issues, be pronounced in the marketing strategy and planning of future events. From the attendees' perception, superlative attributes of Ojude Oba Festival of Ijebu-Ode are equestrian display, the music and the Regberegbe. Income level and source of information are pointers to means of media reach most affordable to the attendees. It is noteworthy that although Ojude Oba Festival has a global audience and attendance, yet it is a cultural festival of the people of Ijebu therefore, the attendees' motive to meet old and new friends is the major factor driving their overall satisfaction with the festival. 


\section{Conclusion and recommendations}

The findings of this study shows that the majority of the attendees are youth whose motivation for attending the festival is majorly cognitive that is, desirous to explore, seeking intellectual development or to acquire information. The satisfaction of the attendees with the festival is based on the attributes of horse riding, music and regberegbe, $36 \%$ respondents are satisfied and $50 \%$ are very satisfied, $93.6 \%$ have the intention to revisit while $87 \%$ will recommend the festival to others.

It is hereby recommended that other recreational activities that will boost cultural knowledge of the attendees be introduced in order to satisfy the teeming inquisitive attendees; such activities may include riddles, Yoruba adages, historical folklores and/or folktales, relating the festival attributes to their root/origin in traditional Yoruba lifestyle, etc.

\subsection{Limitations of the study and directions for future research}

This study is limited in the area of days of experience of the attendees, future studies may spread administration of the questionnaire across different days of the festival; it will also be of great significance to the body of knowledge if future researchers anchor their study on festival organisers, sponsors, traders, and other personnel involved in the festival administration. Finally, future studies may use larger scale survey to enhance the accuracy and reliability of results.

\section{References}

Abubakar, B. and Mavondo, F. (2014) 'Tourism destinations: antecedents to customer satisfaction and positive word-of-mouth', Journal of Hospitality Marketing and Management, Vol. 23, No. 8, pp.833-864.

Akhoondnejad, A. (2016) 'Tourist loyalty to a local cultural event: the case of Turkmen handicrafts festival', Tourism Management, Vol. 52, pp.468-477.

Areo, O.M. (2016) 'Regbe-Regbe: multidimensional impact of cloth and colour in Ojude-Oba Festival', International Journal of Humanities and Social Sciences (IJHSS), August-September, Vol. 5, No. 5, pp.55-72, ISSN(P): 2319-393X; ISSN(E): 2319-3948

Báez-Montenegro, A. and Devesa-Fernández, M. (2014) 'Motivation, satisfaction, and loyalty in cultural participation: the case of a film festival', 18th International Conference on Cultural Economics, Montreal, 24-27 June.

Barnes, S.J., Mattsson, J. and Sorensen, F. (2014) 'Destination brand experience and visitor behaviour: testing a scale in the tourism context', Annals of Tourism Research, Vol. 48, No. C, pp.121-139.

Chang, W. and Yuan, J. (2016) 'A taste of tourism: visitors' motivations to attend a food festival', Event Management, Vol. 15, No. 1, pp.13-23.

Chen, C.C., Huang, W.J. and Petrick, J.F. (2016) 'Holiday recovery experiences, tourism satisfaction and life satisfaction - is there a relationship?', Tourism Management, Vol. 53, pp.140-147.

Crompton, J.L. and McKay, S.L. (1997) 'Motives of visitors attending festival events', Annals of Tourism Research, Vol. 6, No. 4, pp.425-439. 
Csapo, J. (2012) 'The role and importance of cultural tourism in modern tourism industry', in Kasimoglu, M. (Ed.): Strategies for Tourism Industry - Micro and Macro Perspectives, ISBN: 978-953-51-0566-4, InTech [online] http://www.intechopen.com/books/strategies-fortourism-industry-micro-and-macroperspectives/the-role-and-importance-of-cultural-tourismin-modern-tourism-industry.

Cuadrado-García, M., Pérez-Cabañero, C. and Montoro-Pons, J.D. (2017) 'Managing satisfaction in cultural events. Exploring the role of core and peripheral product', Management, Vol. 22, No. 1, pp.157-174.

Dube, L. and Meon, K. (2000) 'Multiple roles of consumption emotions in post-purchase satisfaction with extended service transactions', International Journal of Service Industry Management, Vol. 11, No. 3, pp.287-304, DOI: 10.1108/09564230010340788.

Diyaolu, I.J. (2010) 'Role of dress in socio-cultural events among the Ijebu-Yoruba, Ogun State, Nigeria', JHER, December, Vol. 13, pp.35-41.

Fahm, A.G.O. (2015) 'Ijebu Ode's Ojude Oba Festival: cultural and spiritual significance', SAGE Open, January-March, pp.1-11, DOI: 10.1177/2158244015574640.

Femi, K. and Adesiji, O.P. (2019) 'Use of smartphones in Moshood Abiola Polytechnic, Abeokuta, Nigeria and the gratification concept: a factor analytic report', Global Journal of Arts, Humanities and Social Sciences, Vol. 7, No. 2, pp.38-51.

Hosany, S. and Gilbert, D. (2010) Measuring Tourists' emotional experiences toward hedonic holiday destinations', Journal of Travel Research, Vol. 49, p.513, DOI: 10.1177/004728 7509349267.

Iolanda, M.B., Patrícia, O.V., Manuela, G. and Júlio, M. (2014) 'Visitors' motivations, satisfaction and loyalty towards Castro Marim Medieval Fair', Journal of Spatial and Organizational Dynamics, Vol. 2, No. 1, pp.89-104.

Kau, A. and Lim, P.S. (2005) 'Clustering of Chinese tourists to Singapore: an analysis of their motivations, values and satisfaction', International Journal of Tourism Research, Vol. 7, Nos. 4-5, pp.231-248.

Kocabulut, O. and Kilcarsalan, D. (2017) 'Motivations of festival participants', International Conference on Tourism Dynamics and Trends, Sevilla, June.

Kozak, M. and Rimmington, M. (2000) 'Tourist satisfaction with Mallorca, Spain, as an off-season holiday destination', Journal of Travel Research, Vol. 38, No. 3, pp.260-269.

Lalith, C. and Fredy-Roberto, V. (2013) 'Exploring memorable tourism experiences: antecedents and behavioural outcomes', Journal of Economics, Business and Management, Vol. 1, No. 2, pp.177-181.

Lee, C., Lee, Y. and Wicks, B. (2003) Segmentation of Festival Motivation by Nationality and Satisfaction, Vol. 25, pp.61-70, Elsevier Science Ltd.

Osinusi (2017) 'Press release for the chairman 2018 LOC, Ojude Oba Festival', Ojude Oba 2017 Brochure, Vol. 3, No. 1, p.64.

Owusu-Frempong, Y. (2005) 'Afrocentricity, the Adae Festival of the Akan, African American Festivals, and intergenerational communication', Journal of Black Studies, Vol. 35, pp.730-750.

Ramukumba, T. (2017) 'An evaluation of festival activities as motives for festival attendance: a case study of Strawberry festival at the Redberry farm in George, South Africa', African Journal of Hospitality, Tourism and Leisure, Vol. 6, No. 4, pp, 1-12, ISSN: 2223-814X.

Schuckert, M., Liu, X. and Law, R. (2015) 'Hospitality and tourism online reviews: recent trends and future directions', Journal of Travel and Tourism Marketing, Vol. 32, No. 5, pp.608-621.

Sheth, J.N. (2001) 'Competitive advantages through customer satisfaction', BMA Review, Vol. 2, pp.13-25. 
Tiamiyu, O.A., Adeogun, O., Alabi, A.A. and Osuniyi, V. (2017) 'Exploring opportunities in ecotourism for environmental sustainability', Paper presented at the 2nd Conference of School of Environmental Studies, January, Moshood Abiola Polytechnic, Abeokuta.

Wang, Y. (2016) More Important than Ever: Measuring Tourist Satisfaction, Griffith Institute for Tourism Research Report Series Report No 10, June, ISSN 2203-4870.

$\mathrm{Yu}, \mathrm{L}$. and Goulden, M. (2006) 'A comparative analysis of international tourists' satisfaction in Mongolia’, Tourism Management, Vol. 27, No. 6, pp.1331-1342. 